\title{
Analogi og genealogi: protestantiske reformbuddhismer
}

\author{
JØRN BORUP
}

ENGLISH ABSTRACT: Buddhism's history can be seen as a succession of reformisms. To focus the relevance of the concept, it is understood in this article as a concept measuring significant change within the religion itself and the surrounding community. With three examples from different contexts: 'Protestant Buddhism' in the 19th century Sri Lanka, the Shin Buddhist reform movement in the Japanese Middle Ages, and Japanese diaspora Buddhism in Hawaii, the relevance of the term is investigated in relation to both genealogical and analogical reference to the Christian Protestant Reformation.

DANSK RESUME: Buddhismens historie kan ses som en lang række af reformismer. For at afgrænse begrebets relevans anvendes det $i$ denne artikel om markante forandringstiltag med betydning for religionen selv og det omkringliggende samfund. Med tre eksempler fra forskellige kontekster: 'Protestantisk buddhisme' i det 19. årh-. på Sri Lanka, shin-buddhistisk reformbevægelse i den japanske middelalder samt japansk diasporabuddhisme i Hawaii, undersøges begrebets relevans med genealogisk og analogisk reference til den kristne, protestantiske reformation.

KEYWORDS: Buddhisme; reformisme; Protestantisme; shin-buddhisme; diaspora

\section{Indledning}

Ligesom kristendom er buddhisme typisk for det, man uproblematisk i gamle dage betegnede en 'verdensreligion'. Den er i sit væsen universalistisk, transkulturel, missionerende og som både tankesystem, institution og producent af materiel kultur en transportabel religion. Buddha var selv del af et religiøst marked for asketiske 'udstigere' fra den dominerende brahmanisme, og den tidligste buddhisme var indbegrebet af en reformatorisk bevægelse. Ligesom kristendommen var også den tidlige buddhisme præget af identitetskonstruktion via adskillelse fra traditionen med lige dele videreførelse og nybrud. Historisk buddhisme har en lang tradition for hermeneutiske brud og sekteriske stridigheder, og i bred forstand kan buddhismens historie ses som en lang række af reformer, nogle med større bredde (fx opdelingen mellem hin- 
ayana og mahayana) og andre med mere lokal eller intra-sekterisk relevans. Hierarkisering og graddeling af sandhedspostulater har været del af den elite-religion, hvis efterdønninger naturligvis har bredt sig til masserne med både religiøs, social og politisk effekt.

Jeg vil i denne artikel analysere tre forskellige former for buddhisme-reformisme, anskuet som to forskellige typer. Den moderne buddhisme, som den især kom til udtryk i Sri Lanka i det 19. århundrede, var direkte inspireret af Vesten, og ikke mindst af protestantisk kristendom. Som 'Protestantisk buddhisme' er den således i genealogisk slægtskab med den vestlige kultur og kristne religion. En analogisk relation, hvor der ikke er nogen egentlig 'berøring' eller historisk relation, vil blive eksemplificeret med illustrative cases fra den japanske middelalder. Denne japanske 'reformbuddhisme' vil endelig ses i en moderne diaspora-kontekst i Hawaii, hvor såvel analogiske og genealogiske relationer krydses. Eksemplerne fra den buddhistiske verden vil således illustrere reformisme, forstået som intenderet ideologisk og institutionel transformation, samt begrebets religionsvidenskabelige relevans i historisk og fænomenologisk perspektiv.

\section{Protestantisk buddhisme 1: genealogi}

Buddhismen i Sri Lanka havde siden de første indiske missionærer i århundrederne før vor tid haft status af nationalreligion med et velfungerende klostersystem, politisk autoritet og royal beskyttelse. Sekterisk fraktionering og sydindiske invasioner hørte dog også til middelalderens dagsorden, og invitationer af både burmesiske og siamesiske munke til at genoprette klostervæsenets ordinationsritualer helt frem til det 18 . århundrede siger noget om latent ustabilitet i sanghaens status og vitalitet. At en gruppe munke og lægfolk med inspiration fra en delegation til Burma senere var med til at reformere den kaste-opdelte sangha, ${ }^{1}$ indikerer yderligere de interne kim til forandring. Men det var ydre faktorer, der for alvor var medbestemmende for omkalfatringen af religionen. Med portugisiske og hollandske besættelser af kystregionerne var landet blevet del af Vestens koloniherredømme. Det var dog først, da englænderne indtog kongebyen Kandy i 1815, at Sri Lanka for alvor blev underlagt kolonitidens greb, og buddhismen måtte genfinde sig selv. Selvom der havde været interne konflikter og forsøg på reformer fra både kongers og munkes side tidligere, var det $\mathrm{i}$ det nittende århundrede et egentligt vendepunkt, hvor “Buddhism began to change its character" (Gombrich 1988, 173).

Hvad Gananath Obeyesekere kaldte 'Protestant Buddhism' (1970), er således udtryk for konsekvenserne af sanghaens egen konflikt og ikke mindst den srilankanske buddhismes møde med den britiske kolonimagt. Briterne overtog kontrollen med

1 Selvom kastesystemet i mange af buddhismens dogmer er kritiseret og negeret, har det været integreret som socialt stratifikationsprincip i både kloster- og lægverden i Sri Lanka, især institutionaliseret i Kandy-tiden (1592-1815) (se Samuels 2010). Ligesom det er tilfældet i Nepal, kan dette opdelingssystem tilskrives indflydelse fra hinduismen. Uanset oprindelse illustrerer kastesystemet i buddhismen et kompleks forhold mellem idealer og realiteter, mellem dogmer og levende religion. 
sanghaen, herunder retten til eksklusion af munke. Dette betød i bred forstand, at sanghaens autoritet og tidligere tætte forhold til den politiske magt (kongehuset) blev desavoueret. Koloniherrernes import af indisk (tamilsk) arbejdskraft samt etablering af institutioner baseret på meritokrati og underkastelse til nye magtstrukturer var desuden med til at nedbryde tidligere etniske og kastebaserede hierarkier til fordel for en gryende individualistisk, urban middelklasse.

Kristne (primært anglikanske, metodistiske og baptistiske) missionærer fulgte koloniseringsprojektet op med initiativer til at 'civilisere de indfødte' og egentlig konversion. De fik oprettet skoler til kristne unge, kristne kirker med prædikende præster, og de fik med en for srilankansk kontekst ny bogtryk trykt bibler og pamfletter med kristne og 'vestlige' budskaber. Kristendommen og det engelske sprog blev symbol på magt og økonomisk velstand. Men de blev også set som kanaler til kulturel og symbolsk kapital for en befolkning i byerne, der så modernitetens potentialer for alternative livsformer. Kristendom gik hånd i hånd med fortællinger om modernitet, civilisation, Vesten, videnskab, velstand og teknik.

Missionærernes kampagner og civilisationsprojekter fik en vis succes. Selv blandt munke i templer blev flere af dem modtaget med interesse og med tilbud om brug af templer og biblioteker til en tidlig form for lokal tilpasning. Flere missionærer, herunder den indflydelsesrige metodist Spence Hardy (1803-1868), tog disse positive tilkendegivelsler som udtryk for netop buddhismens naturlige underlegenhed, der ydermere blev forsøgt udstillet med religiøse seminarer, hvor kristendommens angivelige overlegenhed var den strategiske dagsorden. Flere unge munke tog dog til genmæle. Hikkaduwe Sumangala (1827-1911) og Migettuwatte Gunananda (18231890) var to fremtrædende munke, der tog kampen med og inspirationen fra de kristne missionærer op. De deltog i debatmøder, organiserede egne foreninger for buddhister (såsom The Society for the Propagation of Buddhism), tog på prædikenturneer og udgav egne buddhistiske tidsskrifter. Sammen med indflydelsesrige lægbuddhister fik de etableret buddhistiske skoler, der foruden den traditionelle religiøse lærdom også inkluderede tidens sekulære fagligheder, og Sumangala blev rektor for landets første og stadig eksisterende universitet.

Medstifteren af det amerikanske Teosofisk Selskab, Henry Steel Olcott (1832-1907), havde læst om disse buddhister med deres nye tiltag. I 1890 ankom han sammen med Madame Blavatsky (1831-1891) til Sri Lanka. Sammen tog de de buddhistiske tilflugter, og Olcotts aktiviteter og indflydelse på buddhismens fornyelse er siden blevet del af den moderne buddhismes historie. Han oprettede et Buddhistisk Teosofisk Selskab (BTS) og var med til at etablere en Young Men's Buddhist Organisation. Han designede det stadig universelt anvendte buddhistiske flag (fig. 1) ${ }^{2}$ og skrev og fik udgivet (trykt i 40 udgaver og oversat til 20 sprog) en buddhistisk katekismus på engelsk, der siden har været brugt i buddhistiske skoler i mange lande. Han fik indført buddhistiske sange og kort til højtiden wesak (som pendant til kristne julesalmer og -kort), og med fundraising-kampagner fik han etableret en række buddhistiske skoler og organisationer. Med den lokalfødte og senere nationalhelt Anagarika Dharmapala (1864-

2 Se billeder bagerst i artiklen. 
1933; fig 2.) dannede Olcott par som buddhismens fornyer og redningsmand. Dharmapala gik selv i katolsk skole, men var praktiserende buddhist i sin fritid. Hos teosofien så han de muligheder for organiseret modstand mod den vestlige kolonimagt, som hans ungdomssind efterlyste. Han blev en ledende figur i BTS og i det gryende samarbejde omkring det indiske Mahabodhi buddhist-tempels restaurering og nye status som internationalt buddhisme-symbol. Som buddhistisk repræsentant i det store World Parliament of Religions i Chicago 1893 blev symbolet på den moderne buddhisme slået fast: Dharmapala som den veltalende retoriker, der i eksotisk klædedragt, men med genkendelig og vidende tale ikke bare var kristendommens og den vestlige verdens modsvar, men også dens sejrrige alternativ.

Sri Lanka og på den internationale scene ville Dharmapala reformere buddhismen. Det gjorde han ved både at kritisere klostervæsnet (for at være for traditionalistisk og hierarkisk), sine lægbuddhistiske landsmænd (for at være for passive og folkereligiøse) og de kristne missionærer og kolonialister (for at være undertrykkende og imperialistiske). Parolen lød på lægmands-engagement med studier af buddhistiske skrifter (på engelsk og sinhala), meditation (som før var forbeholdt munkene i klostrene) og en politisk aktivisme, hvori buddhismen spillede en afgørende rolle som opdragende værdi og national-etnisk identitetssymbol. Projektet med det reformatoriske engagement blev bakket op af flere munke og især veluddannede, urbane lægbuddhister, for hvem en moderne individbaseret religiøsitet var et dragende ideal. Det 'protestantiske' bestod i en hybrid af direkte import fra de kristne missionærer (prædikener, prædikenstil, skriftliggørelse af religion, frelse ved egen tro/praksis uden om et magtfuldt kleresi), koblet med en ny 'vestlig' teknologi (trykkerier, nye transport- og kommunikationsmidler) og forankret i en lokal kontekst, hvis religiøse, sociale og politiske rammer var med til at godtgøre forandringernes vinde. Som buddhismeforskeren Richard Gombrich rammende skriver: "As has happened when the Buddha first preached, the urban middle class seized the religious leadership; Buddhism for the second time began a Protestant reformation" (Gombrich 1988, 174). ${ }^{3}$

De reformbuddhistiske ideer bredte sig som international inspiration til andre asiatiske lande. Netværksrelationer og markante personligheder var med til at give denne en kulturel udbredelse, primært hos det urbane og veluddannede segment. Teosofien var for både buddhismen og hinduismen en katalysator for den postkoloniale reformisme, hvor elementer fra vestlige og østlige esoteriske traditioner blev koblet til hybrider med tiltrækningskraft i både øst og vest. I Japan, hvor Olcott og Dharmapala via missionsrejser også havde sine (dog noget mere tidsbegrænsede) sejrsgange, var denne moderne form for buddhisme også medvirkende til, at D. T. Suzuki og dennes 'protestantiske Zen' (Sharf 1995; Borup 2018) blev inspirationskilde også til en vestlig buddhisme. De 'vestlige' og 'østlige' ideer og institutioner blev således tilpasset, forhandlet, reformuleret, eksporteret og cirkuleret som autentisk buddhisme i en transnational og senere global kontekst. Dharmapala var også kendt blandt de få daværende danske buddhister. Han korresponderede med overlægen

Dharmapala er efterhånden blevet et ikon for buddhismen og for forskning i moderne buddhisme. Gode indføringer hertil er Gombrich 1988; Gombrich \& Obeyesekere 1988; Kemper 2015. 
Christian F. Melbye og opfordrede denne til at danne en buddhismegruppe. Melbye grundlagde derfor foreningen Buddhistisk Samfund i Danmark, og blev selv den danske repræsentant i Mahabodhi Society, en international buddhistisk bevægelse etableret af Dharmapala. Dharmapala selv blev inviteret til at holde foredrag på Askov Højskole i 1904, hvor det fremkaldte eksotiske oplevelser at se "den smukke Mand med den mørke Ansigsfarve og det stærke sorte Haar staa paa Katederet og tale i sin gule østerlandske Dragt" (Schrøder 1904, 300). Foredraget var muligvis arrangeret af en vis Gudrun Friis Holm, som han angiveligt havde et ganske nært (omend muligvis udelukkende platonisk) forhold til (Kemper 2015, 103ff).

Den protestantiske buddhisme er stadig i dag en underforstået skabelon for megen urban læg- og munkebuddhisme med lige dele 'lægorientering af monastisk buddhisme' (egalisering, individualisering og aftraditionalisering) og 'monasticering af lægbuddhismen' (skriftstudier, meditation og nirvana til alle). Dharmapalas inspiration fra og opgør med vestlig dominans har desuden direkte ansporet senere generationer af politisk engagerede munke (i både Sri Lanka og senere Myanmar) til promovering af en stærkt nationalistisk form for buddhisme. Retorisk italesættelse af identitet mellem religion, etnicitet, sprog og nation har for de højreorienterede grupper Jathika Hela Urumaya ('National Heritage Party') og Bodu Bala Sena ('Buddhist Power Force') været del af en diskurs og aktivistisk praksis, der sammen med parallelle udviklinger i Myanmar har givet buddhismen kontemporære ridser i lakken. Ligesom den protestantiske reformation i Europa var med til at skabe tætte bånd mellem kirke og stat, har protestantisering af buddhismen således også været med til at nationalisere buddhismen og 'buddhificere nationen'.

Denne form for reformatorisk neo-buddhisme havde sit udgangspunkt i Sri Lanka, men stod via kolonimagten i direkte og genealogisk relation til den protestantiske reformation i Europa via et netværk af buddhistiske munke og lægfolk, teosoffer, missionærer og orientalister. Næste eksempel på reformbuddhisme har derimod ingen genealogisk slægtskab hertil. Den opstod før både Luther og Dharmapala og udgør således en religionsfænomenologisk analogi til den kristne reformation.

\section{Protestantisk buddhisme 2: analogi}

En vandring gennem et japansk tempel tilhørende Rene Lands-buddhismen giver på mange måder samme eksotiske indtryk som vandringer gennem templer tilhørende zen-, nichiren-, tendai- eller shingon-skolerne. Rene Land-buddhismens slægtskab med zen- og nichiren-templerne er da også ganske naturligt, da de alle tre var del af den 'nye buddhisme', som i Kamakura-tiden (1185-1333) blev etableret og siden bredte sig til hele Japan. Som reaktion på de esoteriske tendai- og shingon-skolers magtmonopolisering anså de tre nye retninger sig som reformatoriske. På hver deres måde ville de tilbyde sig som alternativer på markedet med en lære, praksis og institution, der også havde relevans uden for den sociopolitiske elite. Samtidig havde de 
hver deres bud på en soteriologisk vej i 'de sidste tider' (mappō). ${ }^{4}$ Munken Nichiren (1222-1282) var en kraftfuld retoriker, hvis skrydende kritik af andre buddhist-institutioner bragte ham eksilering, men også anseelse for eftertiden. Zen-skolerne såede kimen til en buddhistisk proto-kapitalisme (Collins, 1997) med et klostersystem, der var vendt mod omverden og deltog i både den materielle og immaterielle udvikling af samfundet. Alle tre skoler bidrog til en fornyelse og 'japanisering' af buddhismen, både i forhold til lære, praksis og den socio-politiske indlejring i samfundet, omend Kamakura-buddhismens rolle som reformator og genoprejser af tidligere dekadent buddhisme mest er udtryk for senere tids apologetisk historieskrivning. Men det var og er Rene Lands-buddhismen, der tydeligst er analog til både den europæiske og srilankanske protestantiske reform nogle århundreder senere. ${ }^{5}$ Nærmere studier af dens lære og praksis, indsigt i dens organisation og fornemmelse af den 'protestantisk-præstelige habitus' giver da også indtryk af en religion med klare konnotationer til både japansk, buddhistisk og 'protestantisk' kultur.

Det var munkene Hōnen (1133-1212) og dennes discipel Shinran Shonin (11731263; fig. 3), der grundlagde den japanske Rene Lands-buddhisme. Begge havde de tilbragt flere år på det magt- og prestigefyldte tendai-buddhistiske klosterkompleks på Hiei-bjerget uden for Kyoto. Begge var de blevet udlært og dannet ind i elite-buddhismen med dens spekulative mahayana-filosofi. Og begge var de desillusionerede af samme, tilskyndet til reform og protest, om end mindre konfrontatorisk end den, Nichiren blev berømt og berygtet for. Hōnen etablerede en ny sekt, senere institutionaliseret som Rene Lands-sekten, Jōdo sh $\bar{u}$, og fik straks tilhængere blandt masserne. Løftet om frelse ved recitation af mantraet Namu Amida Butsu (æret være Amitabha Buddha) et tilstrækkeligt antal gange var en vej, de fleste uden for klostrene kunne forstå. Det var en praksis, der gik tilbage til kinesisk Rene Lands-buddhisme, hvor man skelnede mellem to forskellige tilgange til den buddhistiske oplysning; en soteriologisk 'svær vej' for eliten og munkene baseret på 'selv-kraft' og en 'let vej' for masserne baseret på frelse ved 'anden-kraft'. ${ }^{6}$

4 I den japanske middelalder mente mange, at den sociale virkelighed var tegn på den buddhistiske forfaldstanke om 'de sidste tider' før en ny Buddhas genkomst.

5 Karl Barth sagde om den japanske Rene Lands-buddhisme, at den udgør "the most exact, comprehensive, and plausible 'pagan' parallel to Christianity" (Barth 1961, 1,2: 342). Det siges, at de første jesuit-missionærer i det 16. århundrede var skuffede over at finde de sørgelige resultater af protestantisk mission. Først senere gik det op for dem, at Rene Lands-buddhismen faktisk var ganske 'autentisk' og 'ubesmittet' af protestantisk mission.

6 Ideer om det Rene Land (sukhavati) går tilbage til tidligere indisk buddhisme som udtryk for det sted, hvor man opholder sig sammen med Amitabha Buddha inden næste genfødsel. Det Rene Land blev først institutionaliseret som selvstændig tankeretning i Kina og blev først i Japan en egentlig selvstændig skole med dertil hørende underskoler. At anskue Rene Land-buddhismen som en helt adskilt retning, isoleret fra andre typer af og skoler inden for buddhismen er dog primært en moderne konstruktion, ikke mindst inspireret af vestlig kategorisering af religiøse 'ismer', 'verdensreligioner' og opdeling i adskilte religioner (Yu 2014, 202ff). Selvom de kinesiske rødder til Rene Lands buddhismen har tydelige referencer i den japanske ditto, er det ofte tilskrevne genealogiske slægtskab mellem kinesiske Rene Lands buddhister som Tanluan, Daochuo og Shandao og deres japanske sidestillede Hōnen og Shinran ligeledes mest en konstruktion fra det 19. århundrede (ibid., 205). 
Shinran gik i sin radikalitet endnu længere med sin Sande Rene Lands-buddhisme, (institutionaliseret som Jödo shinsh $\bar{u}$, eller forkortet til den generiske betegnelse 'shinbuddhisme'). Har man, proklamerede han, den rette tro (shinjin), er det nok at recitere Namu Amida Butsu bare én gang, så vil Amida (det japanske navn for Amitabha Buddha) med sin nådegave på forhånd frelse en i dette liv med henblik på den endelige frelse i det Rene Land efter døden. En sådan praksis er nemlig baseret på den nødvendige 'anden-kraft' (tariki) i modsætning til de andre buddhistskolers opfordring til frelse ved 'egen-kraft' (jiriki), og dermed 'gerningsretfærdige' og instrumentalistiske sindelag. ${ }^{7}$ Et etisk korrekt liv med mådehold og dennesidig tilfredshed blev da idealet for de 'vidunderlige, lykkelige mennesker' (myōkōnin), der i modsætning til den asketiske (shukke, 'at gå ud') buddhisme udgør grundlaget for den nye lægmandsbuddhisme (zaike, 'hjemmegående'). Shinran identificerede sig som 'hverken munk eller lægmand'. Han blev senere gift og fik syv børn. Organisatoren af shinbuddhismen Rennyo (1415-1499) blev gift fem gange, og fik i alt 27 børn. Begge kritiserede samtidens angiveligt hykleriske askese-idealer og talte varmt om ægteskabet som institution for også klerikale buddhister. Efter den japanske åbning mod Vesten i årene efter Meiji-restaurationen i 1868 blev den shin-buddhistiske ægteskabstradition standard for også andre buddhistsekter, herunder dem, der identificerer sig som asketiske. ${ }^{8}$ I dag er det kun et lille mindretal af buddhistpræster, der ikke er gift, og kvindelige præster er alment anerkendt og en relativt udbredt tradition.

Shin-buddhismen havde og har sin doktrinære begrundelse i Shinrans lære, der gjorde op med et asketisk klosterliv og et præsteligt religionsmonopol. "Når selv et godt menneske bliver genfødt i Det Rene Land, så meget desto mere vil et ondt menneske blive det" (Andreasen \& Borup 2013, 121) var således et typisk eksempel på et retorisk greb til at vende om på traditionelle buddhistiske dogmer for at understøtte det radikale paradigme om frelse ved tro alene. Kritik af magiske 'ydre' ritualer med lovning på dennesidig fortjeneste (genze riyaku) har siden Shinran været væsentlige bidrag til den officielle lære, ligesom ofringer, pilgrimsfærd, bøn som ønskeritualer og karmisk merit-overførsel til forfædre har været anskuet som dogmatisk illegitime. Ritualers ordmagi blev transformeret til opbyggelige prædikener, og i bred forstand kan man sige, at Shinran lagde kimen til at omdanne klosterbuddhisme til 'kirkebuddhisme', hvis ydre kendetegn er templernes arkitektoniske minimalisme.

7 Denne polemik mod fortjenstfulde handlinger ('gerningsretfærdighed') findes dog også internt i fx kinesisk chan- og japansk zen-buddhistisk diskurs som en underliggende hermeneutisk og eksistentiel problematik. På den ene side fordres idealer om netop ikke at sætte egen bestræbelse ind som instrumentelt middel til oplysningen. På den anden side er klostervæsenet med diverse rituelle metoder (ikke mindst meditation) anskuet som det traditionsopretholdende kvalitetsstempel.

8 'Asketisk' forstås i denne forstand som 'klosterlig', hvad her til hører af forordninger for livsførelse. Kloster-buddhismer som zen, tendai og shingon har dog typisk kun et egentligt klosterliv integreret i karrieren som en midlertidig periode (typisk 1-2 år), før 'tilbagevenden' til familiens tempel med familieliv og status som præst. Også shin-buddhismen har dog stadig behov for at markere en forskel mellem klerikal og lægorienteret buddhisme, med tegnene for 'munk' (sōryo) til betegnelse af førstnævnte og 'læg' eller 'hjemmegående' til betegnelse af sidstnævnte. 
Den reformatoriske og 'simple' shin-buddhismes doktrinære indhold og institutionelle struktur er således ganske sammenligneligt med luthersk kristendom. Ligesom denne blev også shin-buddhismen en anstødssten for de etablerede 'gamle' retninger, og flere bondeoprør blev i religionens navn rettet mod magthaverne (shogunatet), der til gengæld igangsatte forfølgelser, brændte templer ned og forbød fremsigelse af bønnen til Amida Buddha. Ligesom luthersk kristendom blev shinbuddhismen senere del af mainstream-kulturen, og besindede sig selv på at være del af det politiske etablissement. Som en pendant til den lutherske to-regimentelære blev det en officiel doktrin, at man accepterede en magtfordeling mellem en buddhistisk og en verdslig lov (shinzoku nitai). Shin-buddhismens sociale engagement med opskrifter på religiøs og social transformation var sammen med dens 'tro alene'-doktriner desuden sammenlignelige som grundlag for en 'protestantiske etik' med opsparing af god karma i dette liv med henblik på et liv i paradis efter døden, konkret illustreret af religiøse handelsmænd i shin-buddhistiske 'tempelbyer' (jinai) i 1500-tallet religion. ${ }^{9}$

Den japanske middelalders reformbuddhisme, tydeligst udtrykt ved shin-buddhismen, var således analog til den protestantiske reformkristendom. Med åbningen mod Vesten og moderniteten blev denne analoge relation yderligere udbygget med en genealogisk relation. Vestlige idealer inden for politiske, sociale, kulturelle og økonomiske områder blev på forskellig vis inkorporeret i Japan, ligesom religiøse reformer fik nye udtryk. Buddhistiske reformatorers modsvar til den gryende nationalismes favorisering af shinto som statsreligion og de nye (nu primært protestantiske) kristne missionærers udbredelse, var modernisering af religionen, ikke mindst inspireret af den internationale 'protestantiske buddhisme' (se ovenfor). På sin vis kan man sige, at shin-buddhismens idealer om af-ritualisering, afmytologisering, rationalisering og egalitær lægmandsbuddhisme var godt klædt på hertil. Denne folkelige buddhisme har på mange måder samme kulturreligiøse relevans som en rummelig dansk folkekirke, selvom førstnævnte ikke har samme de facto-monopolstatus. Dette giver sig udslag i en tilsyneladende korrespondens mellem officiel teologi og shinbuddhisters tro, værdier og sociale etik (Dessi 2010) på den måde, at religiøse idealer synes indoptaget som også religiøs habitus. Omvendt har en sådan teologisk set stringent protestantisk religion ikke nødvendigvis udbredelse i praksis. Anskuet som levende religion med fokus på ritualer og performativitetsteorier (Yu 2014, 213ff) bliver også japansk shin-buddhisme folkelig med både ritualer, præster, forfædretro og tro på dennesidig fortjeneste. Intellektuelle teologer forsøgte da også, i kølvandet på 1980ernes dekonstruktivistiske bølge, at formulere en mere realistisk 'katolsk shin-

9 Hvis man godtager Webers tese om oprindelsen til kapitalismen i den protestantiske etik (og dennes indplacering i en europæisk kontekst, der dannede grundlag for en sådan), vil en parallel til japansk shin-buddhisme være snublende nær. Religionen i sig selv synes at have samme potentiale til en sådan kulturel og økonomisk transformation. Men der var også forskelle i de religiøse og socio-politiske konfigurationer. Shin-buddhismen var blot en af flere buddhistiske grupperinger i et religiøst pluralistisk Japan og ikke en egentlig dominerende faktor i det politiske landskab, der i den japanske middelalder længe forblev hierarkisk opdelt. Ligesom det kan siges om zen-buddhismen (hvis egalitaristiske og transgressive lære primært var retorisk, og ikke med sociale transformationer for øje), havde den japanske shin-buddhisme dog potentiale som leverandør af 'proto-kapitalistisk' etik. 
buddhisme', der kom brugerne i møde på en mere åben måde. Disse havde en vis intellektuel gennemslagskraft, men kun lidt praktisk betydning for dogmatikken og de institutionelle strukturer (Borup 2016). Man kunne, med en vis parallel til dansk folkekirkekontekst, sige, at den reformatoriske religion har haft betydelig effekt, men at dens stringente tros- og dogmefokuserede teologi er udfordret dels af den levende religions før-reformatoriske praksis og tankegods, dels af stigende sekularisering og individualisering, for hvilken de reformatoriske præmisser ikke nødvendigvis længere har samme indlysende gyldighed.

\section{Protestantisk buddhisme 3: analogi og genealogi}

Et tredje eksempel på reformatorisk, protestantisk buddhisme kobler den analogiske og genealogiske relation, ligesom den som en japaniseret form for indisk buddhisme i en transnational diasporakontekst i USA forbinder og overskrider kulturelle grænser.

Da efterspørgslen på asiatisk arbejdskraft til sukkerrørsplantagerne i Hawaii og Californien havde nået Japan, var landet allerede midt i Meiji-tidens moderniseringsperiode. Religionen, de snart fik med sig og etableret i lokale omgivelser, var derfor på vej til at blive klædt på til en moderne, og mere international verden. De forskellige buddhistiske skoler (og enkelte shinto-organisationer) fik via japanske missionærer snart rodfæste med templer, præster, gravpladser, og - som tegn på religionens transkulturelle relevans i det nye 'little Japan' - teceremonier, blomsterarrangementer, kvindegrupper, spejderklubber og sprogskoler. Religionens markant etniske karakter fik dog efterhånden også sine parallelle ikke-etniske udtryk. Den første japanske (shin-buddhistiske) missionær Imamura Emyo (1867-1932) insisterede på at domesticere religionen og at assimilere den til den amerikanske sproglige, kulturelle og religiøse kontekst. Sammen med den britiske konvertit og buddhistpræst Ernest Shinkaku Hunt (1876-1967) etablerede han søndagsskoler og Young Men's/Women's Buddhist Associations, forfattede buddhistiske salmer (hymns) og bøger på engelsk og konstruerede buddhistiske gudstjenester (services) med prædikener og prædikenstol, orgelmusik og kirkebænke (fig. 4). Det var især de to, der var med til at levendegøre den generelle protestantisering af buddhismen i Hawaii med kristne standarder for aktiviteter, ritualer og organisatoriske strukturer, herunder 'menighedsgørelse' (congregationalization) med bestyrelser og menigheder i den buddhistiske 'kirke' (church). Da Imamura ordinerede Hunt og dennes kone Dorris, var det givetvis med strategisk bevidsthed om, at de var "like lemons on a lime tree, devoid of Japanese ancestral religion" (Tanabe 2005, 89). Efter en første inkorporationsfase med stærk etnificering skulle næste fase baseres på tilpasning og med lige dele japansk og amerikansk kulturel kolorit. Hunt selv havde mødt buddhismen på rejser i Asien og havde studeret religionen i Rangoon. Den buddhisme, han selv promoverede på Hawaii, var dybest set en moderne, protestantiseret Theravada-buddhisme à la Dharmapala, og det er karakteristisk, at Shinran end ikke nævnes i hans Catechism for 
Buddhist Sunday Schools (ibid, 90) $\cdot{ }^{10}$ Kombinationen af en analogisk protestantisme (shin-buddhisme baseret på Shinrans lære) og en genealogisk relateret protestantisme (srilankansk reformisme som udtrykt ved Dharmapala og effektueret lokalt ved Hunt) med tydeligt afbalancerede transnationale og -kulturelle ingredienser så i 1920erne og 1930erne ud til at være opskriften på succes, som en 'lotus i paradis' (Tanabe, 2000).

George Tanabe antager to primære faktorer bag den japansk-amerikanske buddhismes senere hendøen: dels Anden Verdenskrig, dels fejlslagen institutionsstrategi. Der var røster af mistænksomhed allerede gennem de sidste år af 1930'erne. Men med angrebet på Pearl Harbour blev det et faktum: Japanerne var fjenden og buddhismen en fjendtlig udløber deraf. Japanere blev diskrimineret, buddhistpræster blev smidt i interneringslejre, og buddhismen blev de facto kriminaliseret. Havde det før været forbundet med prestige at konvertere til kristendommen og mingle med (eller ligefrem gifte sig ind i) kristne familier, blev dette nu en åbenlys strategi til individuel og kulturel overlevelse. Flere antog amerikanske navne, glemte det japanske sprog og kulturelle koder, blev 'amerikaniserede' for fuld musik og med delvis velsignelse fra både forældre og præster, også lang tid efter krigen. Krigens markante effekt på japansk-amerikanernes dalende grad af etnisk og religiøs identitet og tilhørsfølelse samt de efterfølgende årtiers amerikanisering, individualisering og sekularisering (Borup 2013) ville muligvis have kunnet opblødes ved en fornuftig missionsstrategi; men det er ifølge Tanabe her, japanerne selv har fejlet. Efter Iwamuras død i 1932 blev en ny japansk missionær indsat, og hans første fortjeneste var at fyre Hunt og annullere dennes alt for universalistiske reformbuddhisme. Siden da har det i overordnet grad for de fleste buddhistskoler været strategien, defineret fra hovedkontorerne i Japan, at lade institutionen, læren og ritualerne forblive så japanske som muligt. De ydre protestantiske rammer (sproget, kirkerummet, bestyrelsesformen etc.) forbliver, men med kun få mulige tiltag til fornyelse eller faktisk effektuering af også en 'vestligt' inspireret reformisme (i stil med Dharmapala og Iwamura/Hunt). Tanabe kalder templerne "solidly sectarian" (Tanabe, 2005, 96), med en religiøs kultur, der er "westernized on the surface but remains unassimilated at its core" (ibid., 78), hvorfor "Japanese Buddhism in Hawai' $i$ for the last thirty years has been suffering a slow but certain death" (ibid.).

Japansk-amerikansk buddhisme er generelt i krise, og ikke mindst dens status som 'etno-religion' synes at være det identitetsstempel, der sikrer en vis overlevelse, men som samtidig udgør den effektive barriere mod inklusion og fornyelse. Visse steder i USA og Canada har man dog forsøgt at overskride den mono-etniske dimension ved

10 Andre steder i Nordamerika har fortællingen om Shinran som "broadly suspicious of celibate monasticism and celebratory of (vaguely defined) family values" ellers været set som strategisk element til kulturassimilation af shin-buddhismen (Mitchell 2017, 90). Samtidig har fortællingen om denne 'man of the people' bidraget til opfattelsen af shin-buddhismen som anti-intellektuel med den potentielle konsekvens, at denne form for buddhisme marginaliseres fra mainstream vestlig buddhisme (ibid, 92). 
at tilbyde meditation i også shin-buddhistiske templer - en praksis, der kan sammenlignes med protestantisk kristne kirkers genindførelse af pilgrimsfærd. For de fleste euro-amerikanere er og forbliver shin-buddhisme dog 'for protestantisk' med for lidt eksotisk brand value og for lidt meditationsbuddhistisk selvudviklingsperspektiv. Det er, som om den første analoge protestantisering (Shinran) ligger for tæt på protestantisk kristendom til at være interessant, mens den moderne, genealogisk beslægtede reformbuddhisme (Dharmapala), som har været direkte inspireret af vestlig kultur og religion, har fundet tilpas identitet og autoritet i Vesten som autentisk buddhisme - men som på Hawaii aldrig nåede at blive endelig del af den officielle fortælling fra de japanske organisationers side.

\section{Konklusion}

Alle reformer tager noget med sig i bagagen fra det forrige. Noget materiale videreudvikles som delelementer af en længerevarende, stille reform. Andet forgår i mere voldsomt manifesterede dønninger fra blodige omkalfatringer af det bestående. Både ydre omstændigheder og indre spændinger er medkonstituerende rammer for de forskelligartede grader af accept og brug af præ-reformatoriske traditioner, som de nye regimer måtte overtage og reformere.

Buddhismens historie baserer sig på en lang række af fornyelser og sekteriske splittelser, hvor en bred definition af 'reform' ville give en fyldig liste af eksempler på reformbuddhisme. Nærværende artikel har dog ikke været et forsøg på encyklopædisk at karakterisere og kategorisere samtlige, mulige reformbuddhismer. Det har derimod været hensigten at fokusere på to forskellige måder at anvende begrebet reformisme på, nemlig som en reformation af religionen (1) med direkte (genealogisk) relation til den luthersk-protestantiske reformation og som (2) historisk uafhængig af denne, men med sammenlignelige (analoge) karakteristika på reformatorisk transformation. Tre eksempler blev valgt til illustration heraf fra tre forskellige tidsperioder og geografiske steder. Alle tre er interessant sammenlignelige med den protestantisk reformation, hvorfor begrebet 'protestantisk buddhisme' (oprindelig anvendt om reformbuddhismen på Sri Lanka) da også giver en vis betydningsmæssig relevans for også tidligere japansk shin-buddhisme og senere diaspora-buddhisme i Vesten med dens fokus på tro, skriftlighed, lægorientering, kirkeliggørelse, protest mod konkurrenter, og indgroede relation til stat og nation. De tre eksempler viser dog også indbyrdes forskellighed, med varierende effekt af reformerne. Shin-buddhismen fik aldrig, som Protestantismen i Nordeuropa og klosterbuddhismen i Sri Lanka, de facto religionsmonopol. Den vedblev med at være en blandt andre buddhistiske retninger $i$ et religiøst pluralistisk samfund, og den blev først del af en egentlig modernitets- og sekulariseringtendens i forbindelse med den generelle vestliggørelse i slutningen af det 19. århundrede. Den srilankanske reformbuddhisme blev inspirator til en global bevægelse og blev i Vesten nærmest indbegrebet af buddhisme som sådan. Den forblev dog primært en diskurs og praksisform for en urban elite og er i dag mest for- 
bundet med politisk og nationalistisk buddhisme. Diaspora-protestantismen på Hawaii fik aldrig rigtig lov at slå igennem, da den blev bremset af krig og nationalistisk missionsstrategi. I dag er den for 'protestantisk' og med kun begrænset brandingværdi for ikke-japanere, hvorfor den primært eksisterer som eksotisk relikvie fra en for længst assimileret gruppe uden yderligere behov for reform. Forskelligheder til trods viser de tre eksempler både genealogiske og analogiske referencer til den kristne reformation, og peger dermed også på reformisme som et relevant religionshistorisk og -fænomenologisk begreb.

\section{LITTERATUR}

Andreasen, Esben \& Jørn Borup

2013 Japansk Religion. Højbjerg: Forlaget Univers.

Barth, Karl

1961 Church Dogmatics, Edinburgh: T. \& T. Clark; I/2, reprinted in On Religion: The Revelation of God as the Sublimation of Religion, Garrett Green (trans.), London: T. \& T. Clark, 2006.

Borup, Jørn

2013 "Aloha Buddha: - the secularization of ethnic Japanese-American Buddhism", Journal of Global Buddhism 14, 2013: 14-43.

2016 "Propagation, Accommodation and Negotiating Social Capital: Jodo Shinshu Responses to Contemporary Crises", Japanese Religions 40 (1-2), 85-107.

2018 “D. T. Suzuki: post-orientalistisk zentænker". Religionsvidenskabeligt Tidsskrift 67, 32-43. http://dx.doi.org/10.7146/rt.v0i0.103450

Collins, Randall

1997 "An Asian Route to Capitalism: Religious Economy and the Origins of Self-Transforming Growth in Japan", American Sociological Review 62 (6), 843-865.

Dessì, Ugo

2010 "Social Behavior and Religious Consciousness among Shin Buddhist Practitioners", Japanese Journal of Religious Studies 37 (2), 335-66.

Dobbins, James C.

1989 Jodo Shinshu: Shin Buddhism in Medieval Japan, Bloomington and Indianapolis: Indiana University Press.

Gombrich, Richard

1988 Theravada Buddhism. A Social History from Ancient Benares to Modern Colombo. London and New York: Routledge.

Gombrich, Richard \& Gananath Obeyesekere

1988 Buddhism Transformed: Religious Change in Sri Lanka, Princeton: Princeton University Press.

Jaffe, Richard M.

2001 Neither Monk nor Layman. Clerical Marriage in Modern Japanese Buddhism, Honolulu: University of Hawaii Press.

Kemper, Steven

2015 Rescued from the nation: Anagarika Dharmapala and the Buddhist world, Chicago, London: The University of Chicago Press.

Mitchell, Scott

2017 "The Stories We Tell: The Study and Practice of Jodo Shinshū Buddhism", Pacific World: Third Series 19, 81-97.

Obeyesekere, Gananath

1970 "Religious Symbolism and Political Change in Ceylon, Modern Ceylon Studies 1, 43-63.

Samuels, Jeffrey 
2010 Attracting the Heart: Social Relations and the Aestetics of Emotiion in Sri Lankan Monastic Culture. Honolulu: University of Hawai'i Press.

Schrøder, Ludwig

1904 "Et indisk Besøg paa en dansk Højskole, Højskolebladet 10, 299-300.

Sharf, Robert

1995 "Sanbokyodan: Zen and the Way of the New Religions", Japanese Journal of Religious Studies 22 (3-4), 417-58.

Tanabe, George J.

2005 "Grafting Identity: The Hawaiian Branches of the Bodhi Tree", in: Linda Learman, ed. Buddhist Missionaries in the Era of Globalization. Honolulu: University of Hawaii Press, 77-100.

2000 Lotus in Paradise. Buddhism and Japanese American Identity in Hawaii, Japanese Cultural Center of Hawaii.

Yu, Jimmy

2014 "Pure Land Devotion in East Asia", in: Mario Poceski, ed., The Wiley Blackwell Companion to East and Inner Asian Buddhism. Wiley Blackwell, 201-220.

Jørn Borup, lektor, ph.d.

Afdeling for Religionsvidenskab, Aarhus Universitet

$j b @ c a s . a u . d k$

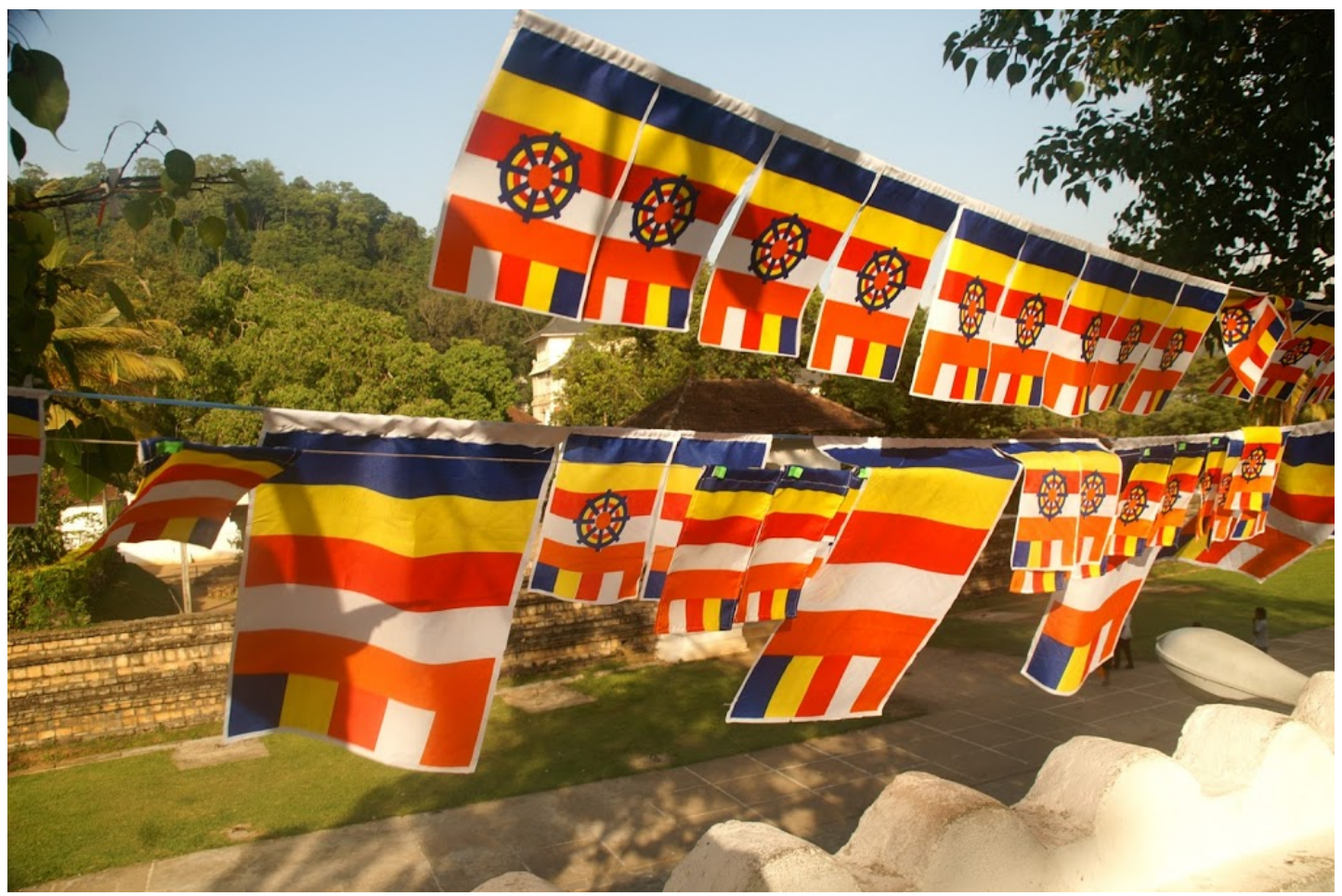

Fig. 1: Buddhistiske flag (foto: Jørn Borup) 


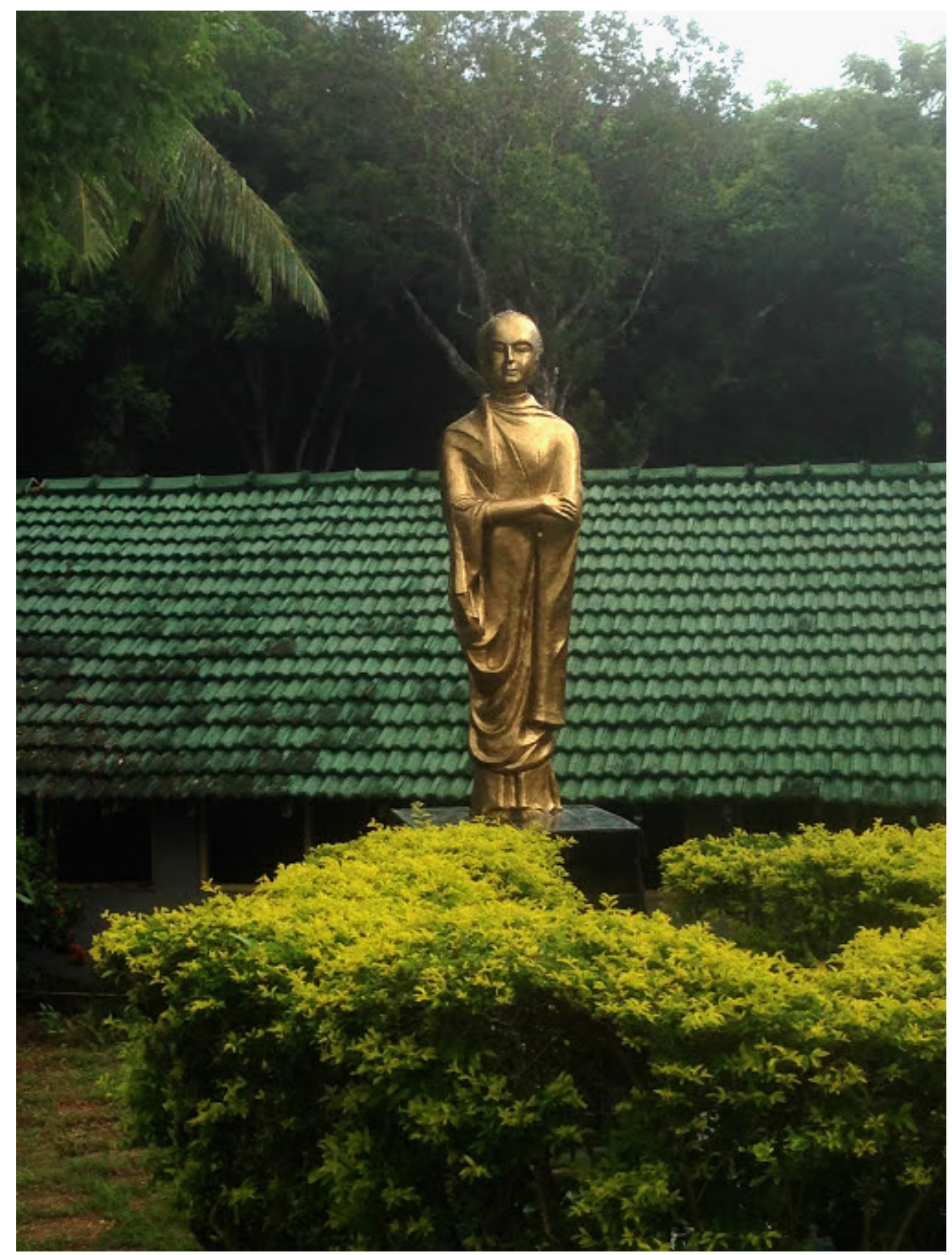

Fig 2. Den buddhistiske reformator Anagarika Dharmapala anses stadig som en kulturhero $i$ Sri Lanka (foto: Jørn Borup) 


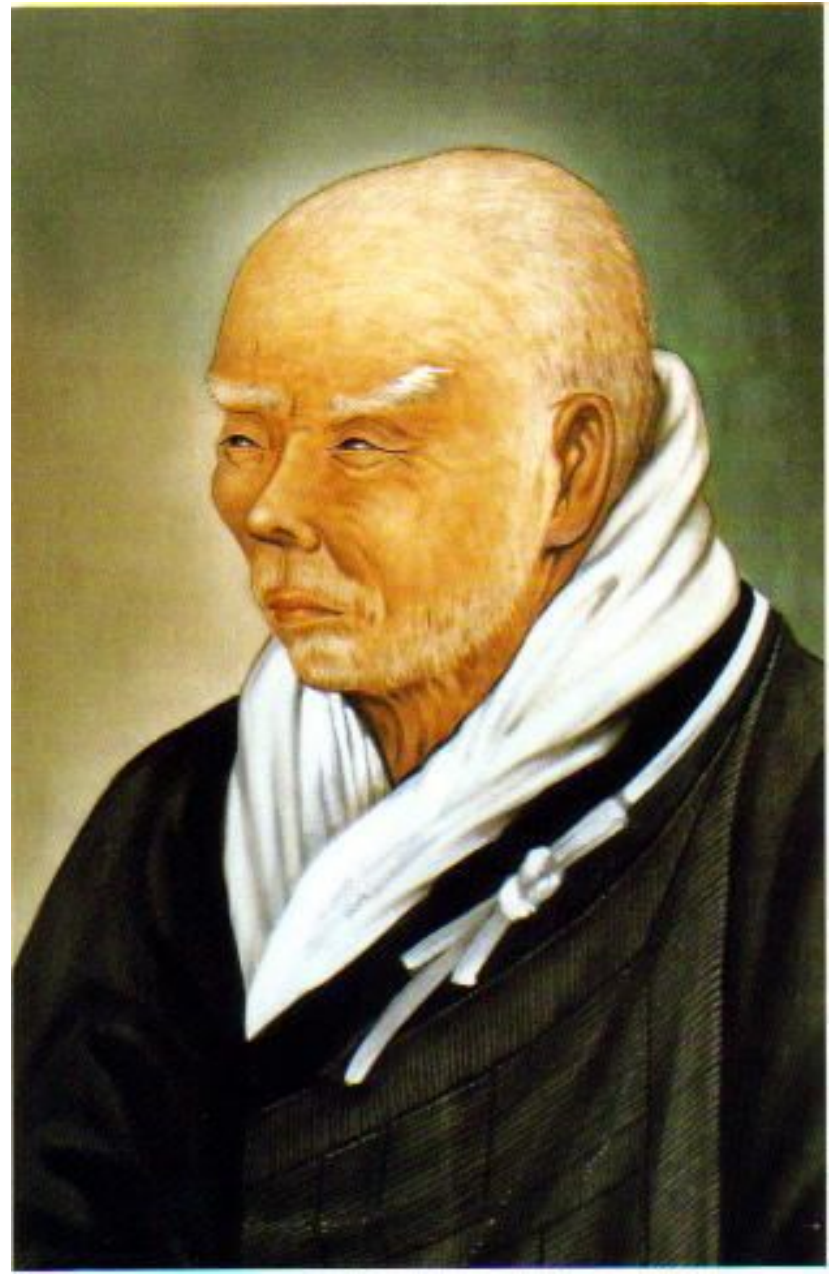

Fig. 3. Shinran Shonin, reformator og grundlxgger af Det Sande Rene Lands buddhisme $i$ Japan (billede: Wikipedia: tilladelse til brug)

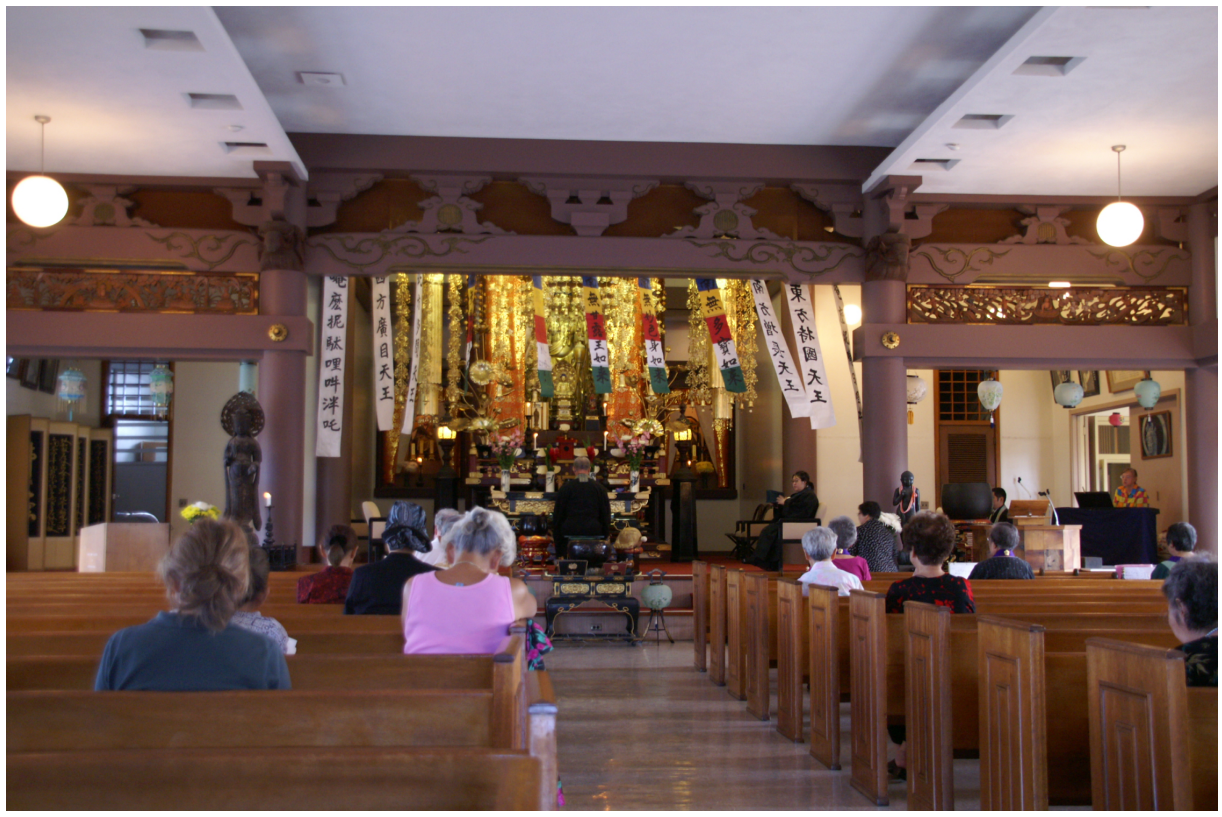

Fig. 4. Typisk kirkerum med alter, prædikestol og kirkebænke i Rene Lands buddhistisk tempel, Hawaii (foto: Jørn Borup) 